\title{
Design and Fabrication of Motorized Maize Shelling Machine
}

\author{
K.A. Adedeji*, N.A. Raji, A. Abolarin \\ Mechanical Engineering Department, Lagos State University, Nigeria \\ *e-mail: kasali.adedeji@lasu.edu.ng \\ Received: $25^{\text {th }}$ August 2016 \\ Accepted: $5^{\text {th }}$ October 2017 \\ Published:16 ${ }^{\text {th }}$ March 2018 \\ https://doi.org/10.47545/etrj.2018.3.1.033
}

\begin{abstract}
Majority of farmers who grow corn cannot afford the high cost of purchasing most of the available imported Shelling machine. Such farmers switch to manual hand shelling method which gives low efficiency, high level of wastage and high labour. This machine was fabricated from locally available material and to shell maize and separate the cob from the grain, at same time, blow the particle. Its cost is very low compared to the imported threshers. The machine was tested to establish the influence of moisture content levels, and the efficiency so as to reduce breakage and wastage during shelling operation. The machine has a power rating of $2.237 \mathrm{KW}$ and shelling capacity of $0.8 \mathrm{ton} / \mathrm{hr}$ with the shelling drum screw rotates at 60 revolutions per minute. This fabricated machine is capable of shelling maize efficiently and economically.
\end{abstract}

Keywords: Blower, breakage, capacity, drum, economical, hopper, shelling

\section{INTRODUCTION}

Grains are fruits of cultivated grasses belonging to the monocotyledonous family called Gramineae [2]. The most commonly found cereal grains in the world are wheat, barely, sorghum, rice and maize. Maize has become a principal commodity produced in West Africa. Maize contains about $10 \%$ proteins, $4 \%$ oil, $70 \%$ carbohydrates, $2.3 \%$ crude fibre, $10.4 \%$ albuminoides and $1.4 \%$ ash. Maize has significant quantities of vitamin A, nicotinic acid, riboflavin and vitamin $\mathrm{E}[1]$.

In Nigeria maize is widely grown both in the Northern and southern parts of the country. This is due to the fact that the climate in the south allows for it to be planted twice in the year. After the harvesting, $40 \%$ of harvested maize is lost every year due to the limitations posed for the farmers by the gross inadequacy of the right equipment for processing after harvest in Nigeria. [4] In some cases most at times, the required agricultural machines are out of reach of the peasant farmers [5].

Traditionally most of the shelling work was done by hand and hand operated maize shelling machine [8]. These two methods were cumbersome for large scale farming because it causes fatigue. There are machines which can shell maize, but these are too expensive for rural farmers. The need of less expensive, eco-friendly solution for shelling maize becomes necessary [4].

After studying existing practices of maize shelling and finding the need of maize Sheller with better performance and customized features, the problem statement has been formed. Traditional shelling is time consuming and there is a problem of labourers and their wages [6]. Hand shelling machine apart from it low cost, its major problem is limitation to output which makes it more less important for a farmer practicing large scale farming as the number of maize to be shelled are numerous [11]. More so, the maize shelling hand device is very slow compare to the motorized shelling machine because, it can only take a maize per operation [7].

\section{LITERATURE SURVEY}

Maize (Zeamas) belongs to the grass family. It is grown everywhere in the world and requires plenty of rainfall and sun for optimum yield. It can be grown throughout the year where farming is mechanized with efficient irrigation system [9].

Maize (Zea mays) is an important cereals crop which belongs to a grass family (Gramineae) producing small edible seeds which was said to have originated from Mexico over years [20]. It is the world's best adapted crop, growing between latitudes $580 \mathrm{~N}$ and $400 \mathrm{~S}$ of the equator. It is a versatile grain crop and commonly known as corn 
in America. The natural endowment of high rainfall, high light intensities, and favourable temperature in the cultivation of maize make it to be one of the world's most versatile seed crops [21]. Maize production in Nigeria is of great

Maize shelling is a post-harvest operation which involves the removal of maize from the cob. Maize shelling therefore is an important step toward the processing of maize to various finished products like flour [18-19].

Maize (Zee mays) also known as corn is one of the most important staple crops in the world. In Kenya, for example, $45 \%$ of the population considers Ugali (maize meal) to be their survival food making it most consumed food of the country. [12] Maize also account for $43 \%$ of the Latin American diet. In Asia, maize production is over 200 billion kilograms a year and it is expected that the total maize production in developing countries will eventually overtake production in industrialization countries. [8]

[13-14] Damage free shelling was attempted using a high speed cutter for milling the cob out of the ear. The corn ears were fed axially against the cutter by a feeding mechanism

According to $[15,22]$, the performance of a thresher depends upon its size, cylinder speed, cylinder concave clearance, fan speed and the sieve shaker speed.

\section{DESIGN AND CONSTRUCTION ANALYSIS}

\subsection{Load Analysis}

The shelling machine has a rotating shaft which will transfer torque or tangential force and in its application for shelling, bending loads are often superimposed on the torsion loads [3].

The shaft for the shelling element is a ductile material. It will support blades and driven pulley. The limiting condition will thus be yielding under static load. If the bending moment, torsion moment and axial force are designated with $\mathrm{M}, \mathrm{T}$, and $\mathrm{F}$ respectively, the diameter of the shaft necessary to prevent shaft failure can be determined. The maximum shear stress theory 'Tresca' is used. The AISI table is used in selecting the alloy ductile material for the application [10].

\subsection{Design and Stress Concentration Factor}

Some factors are important in design problems and are thus treated as factors which reduce the strength of the member or compensate uncertainties in load and strength [16]. The design factor $n_{s}$ is such factor whose value depends on the type of material and the mode of loading. The value of $n_{s}$ is selected from the standard table. It is sometimes convenient to define two factors of safety. $\mathrm{n}_{\mathrm{s}}$ which is one of them is in this case used to account for uncertainties in the strength while the other $n_{L}$ accounts for the uncertainties with regards to load. Thus the total factor of safety could be obtained as;

$\mathrm{F}_{\mathrm{S}}=\mathrm{n}_{\mathrm{s}}+\mathrm{n}_{\mathrm{L}}$

Where $F_{S}$ is applied to strength, we have

$\mathrm{F}_{\mathrm{S}}=\frac{S_{y}}{S_{p}}$

$S_{y}$ is the yield strength and $S_{p}$ is the permissible (design) stress. By rearranging the equation above, the design stress is determined by

$S_{p}=\frac{S_{y}}{F_{S}}$

Where $S_{p}$ is applied to the limiting load $\mathrm{F}_{\mathrm{u}}$ (maxi mum load), we have

$S_{p}=\frac{F_{u}}{F_{p}}$

$F_{p}$ is the permissible load.

Stress concentration effects The stress concentration effects are consequence of holes' grooves, notches or other kinds of discontinuities which alter the stress distribution. It is usually stress that the stress concentration in static loading is very high in brittle materials and less serious in ductile material owing to the relief of stress concentration by plastic flow in the latter. However, it is not generally true that ductility is full insurance against stress concentration. Reduction of concentration is necessary wherever possible without regards to the type of material of which the member is made from. 
The value of bending moment $\mathrm{K}_{\mathrm{b}}$ and Torsion moment factor $\mathrm{K}_{\mathrm{t}}$ are gotten from the American Society of Mechanical Engineers (ASME) table.

\subsection{Machine Components Design}

The Main Frame: The main frame supports the entire weight of the machine. The total weights carried by the main frame are: - weight of the hopper and housing; - weight of the shelling chamber; - the collector and pot; and - the bearings and pulleys. The two design factors considered in determining the material required for the frame are weight and strength. In this work, angle steel bar of 35 by $35 \mathrm{~mm}$ and $2 \mathrm{~mm}$ thickness is used to give the required rigidity.

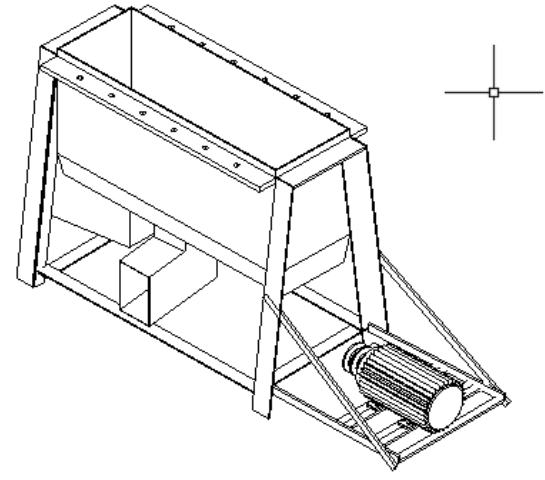

Fig. 1: Support Frame.

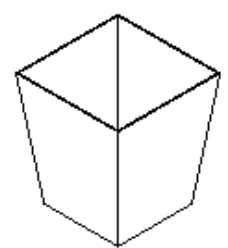

Fig. 2: Hopper

The Hopper: The design of the hopper was made only to be filled in a vertical position only. It shape is like a frustum of a pyramid truncated at the top. The top and the bottom both have a rectangular shape. The material used for the construction is mid steel sheet metal, which is readily available in the market and relatively affordable.

Shelling Pegs and Housing: The pegs are arranged to form a spiral shape (inform of screw conveyor) and are spaced at regular interval so as to ensure the removal of all maize from the smallest cobs.

For this design and purpose, the pegs are vertical and are called blades for design analysis. The more the number of blades, the more is the loss within the blades due to vertex action. Thus, the most appreciable number in design is three, as used in this design having an angle of $120^{\circ}$ to each other and inclination of $45^{\circ}$ to the centre line.

The housing on the other hand is another important part of the shelling unit. The pegs with high speed hit the maize carrying cobs against the housing causing shelling. The housing is best made of metal sheet or mild steel plate of about $3 \mathrm{~mm}$. the bottom part of the housing is flat and contains perforations. The clearance over the bottom part is $15 \mathrm{~mm}$ for the pegs

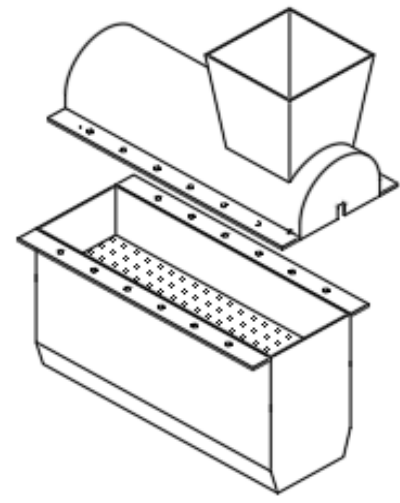

Fig. 3: Upper and Lower Housing

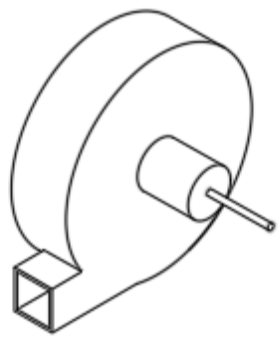

Fig. 4: Blower 
Blower: A mechanical blower is used to blow the shaft away from the cobs. It uses high speed blades to impart velocity to air hence, increasing the speed and the volume. The shaft is attached with a pulley connected to the motor with a belt.

Bearing Selection: Bearing must be selected based on its load carrying capacity, life expectancy and reliability [17]. For selection and determination of bearing for any installation, the following are considered; Radial Load, Thrust Load, Speed and Diameter of the shaft and Desired life bearing.

The equivalent Radial Load defined for rating purpose is expressed as $S_{e}=a S_{r}+b S_{t}$

Where $\mathrm{S}_{\mathrm{e}}$ is the equivalent radial load, $S_{r}$ is the radial load, $S_{t}$ is the thrust load, a is the radial factor, and b is the thrust factor.

The life of bearing, L, expressed in millions of revolutions is as given in equation (6)

$\mathrm{L}=(\mathrm{C} / \mathrm{P})^{\mathrm{n}}$

Where $\mathrm{L}=$ life of bearing, $\mathrm{C}=$ Load Capacity, $\mathrm{P}=$ equivalent Load., $\mathrm{n}=3$ for ball bearings and $10 / 3$ for roller bearing.

The SKF guide was used to value the nominal life, Ln, and life design of maize Sheller falls between 4000 to 8000 hours. For this design, the maximum value is taken.

Hours of Service $\mathrm{L}=8000 \mathrm{hrs}$.

Speed of shaft $\mathrm{N}_{\mathrm{s}}=400 \mathrm{rpm}$

Hence, the number of revolutions $=192 \times 10^{6}$ revs.

The capacity of the ball bearings can be obtained as expressed in equation (7).

$\mathrm{C}=n \sqrt{L} \cdot P$

Such that at point $\mathrm{A}, \mathrm{C}=349.786 \mathrm{kN}$ and at point $\mathrm{B}, \mathrm{C}=444.32 \mathrm{kN}$

According to SKF catalogue the ball bearing that would support this load is Deep Grove ball bearing. Alternatively, Journal bearing could be used if deep Grove ball bearing is not available.

\subsection{Power Transmission Components}

Belt Selection: Belt drive was employed for the transfer of power from the motor to the shaft because of it low cost and flexibility. Belts are frequently necessary to reduce the higher rotational speeds of electric motors to lower values required by mechanical equipment [16].

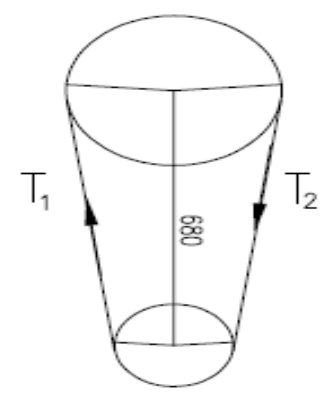

Fig. 5: Tight and slack side Belt tension with pulley

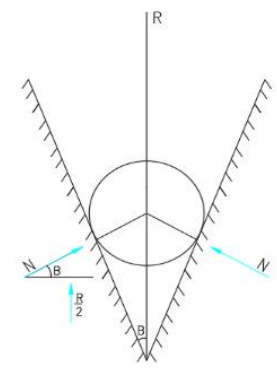

$\mathrm{T}_{\mathrm{m}}=\mathrm{T}_{\mathrm{o}}=1 / 2\left(\mathrm{~T}_{1}+\mathrm{T}_{2}\right)$

Fig. 6: V belt pulley angles 
$\mathrm{T}_{1}=\mathrm{e}^{\mathrm{uai}}$

$\mathrm{U}=\mu / \sin \mathrm{r}$ ( $\mu$ for $\mathrm{V}$ groove belt is 0.14 )

Assume $r$ is $18^{\circ}$, total groove angle $=36^{\circ}$

$\mathrm{T}_{\mathrm{m}}=$ mean effective tension, $\mathrm{T}_{1}=$ effective tension on tight side of the belt, $\mathrm{T}_{2}=$ effective tension on slack side of the belt, $\mu=$ coefficient of friction, $\mathrm{a}^{\mathrm{i}}=$ angle of lap (radian) of the belt.

Pulley Design: For a V-grooved pulley, the normal force between the belt and the pulley is increased since the radial component of the force must equal $R$, if the semi angle of the groove is $\beta$.

$\mathrm{N}={ }^{\mathrm{R}} / 2 \operatorname{cosec} \beta$

Functional resistance $\mathrm{R}=2 \mu^{\mathrm{R}} / 2 \operatorname{cosec} \beta$

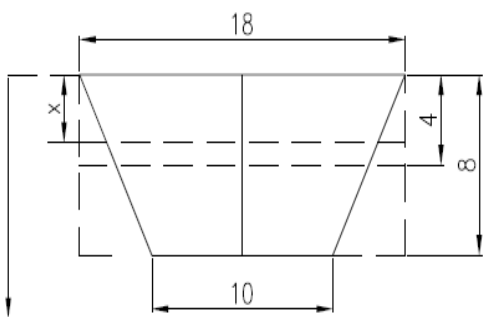

Fig. 7: V section of the Pulley

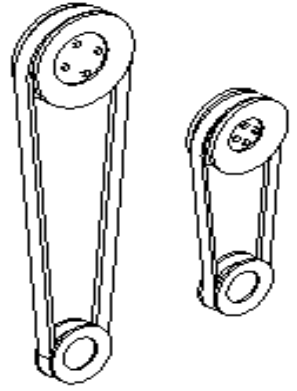

Fig. 8: Belts and Pulleys

If $\mathrm{X}$ is the distance of the neutral axis from the edge $0-0$ of the belt cross section

Area ade $=\frac{1}{2} \times b h$ and area bcf $=\frac{1}{2} \times b h$

Area $\mathrm{abcd}=\mathrm{L}$ X B and area $\mathrm{abfe}=\frac{1}{2}(a+b) h$

Taking moment

Area abfe $X=$ area abcd $X$

\section{Machine pulley speed}

$=$ motor pulley speed $\mathrm{x} \frac{\text { pitch dia.of motor pulley }}{\text { pitch dia.ofM/C pulley }}$

Shaft Design: In shaft design, the load to be carried by the shaft and the reactions at the supports are first established. The loads are:

Weight of driven pulley $=1 \mathrm{~kg}$

$=(1 \times 9.81) \mathrm{N}=9.81 \mathrm{~N}$.

Weight of flat shelling pegs using iron bar,

For each peg, $\mathrm{L}=55 \mathrm{~mm}, \mathrm{~T}=6 \mathrm{~mm} \mathrm{~B}=15 \mathrm{~mm}$

Therefore, for shaft having $800 \mathrm{~mm}$ length, the number of pegs required is

$\frac{800}{55}=14.55$. 
15 pegs were chosen per roll because of clearance on the shaft. These 15 pegs are expected to complete one length roll of the shaft when staggered. Therefore, to complete the 3 rows expected of the design, the number of pegs required is:

$15 \times 3=45$ pegs

But the length of each peg $=55 \mathrm{~mm}$. The total length of bar is $55 \times 45=2475 \mathrm{~mm}=2.48 \mathrm{~m}$.

Volume of Iron bar required is given as:

$\mathrm{V}=$ Area $\mathrm{x}$ Length

$\mathrm{V}=0.055 \times .015 \times 2.48=2.046 \times 10^{-3} \mathrm{~m}^{3}$

Mass is given as the product of volume and density.

Mass $=\left(7680 \times 2.046 \times 10^{-3}\right)=15.7133 \mathrm{~kg}$.

This mass form a uniformly distributed load of $154.15 \mathrm{~N}$

$\frac{154.15}{0.8}=192.68 \mathrm{~N} / \mathrm{m}$

Calculating for the reaction we have, $9.81 \mathrm{~N}$

A

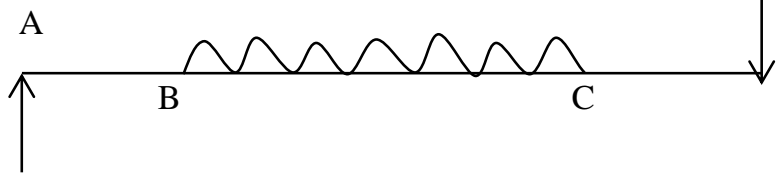

Figure 9

Taking moment around $\mathrm{C}$

$0.9 \mathrm{R}_{\mathrm{A}}+9.81 \times 0.1=192.68 \times 0.4$

$0.9 \mathrm{R}_{\mathrm{A}}=76.089$

$\mathrm{R}_{\mathrm{A}}=\frac{76.089}{0.9}=84.54 \mathrm{~N}$

Therefore, $R_{c}$ is calculated as

Total load $-\mathrm{R}_{\mathrm{A}}=(9.81 \times 192.68)-84.54$

$$
=1805.65 \mathrm{~N}
$$

As follows:

The bending moment at B

$\mathrm{M}_{\mathrm{B}}=0.1 \mathrm{R}_{\mathrm{A}}=0.1 \mathrm{X} 84.54=8.454 \mathrm{Nm}$

The bending moment at $\mathrm{C}$

$\mathrm{M}_{\mathrm{C}}=-(9.81 \mathrm{X} 0.1)=-0.981 \mathrm{Nm}$

Referring to the shear force diagram at B, the shear force rises to $8.454 \mathrm{NM}$, then falls at mid-point. Hence the point $\mathrm{P}$, at which it is Zero, is distant 
$=\frac{8.454}{1708.4}=0.3549$ from

At $\mathrm{P}$ considering forces to the left

$\mathrm{M}_{\mathrm{P}}=168.22 \mathrm{~N}$

Point $\mathrm{A}$ and $\mathrm{C}$ are the bearing supports length $\mathrm{B}$ and $\mathrm{C}$ carry the shelling pegs point $\mathrm{D}$ has driven pulley.

The maximum bending moment $=168.22 \mathrm{Nm}$

$\mathrm{R}_{\mathrm{A}}$ due to bearing support at $\mathrm{A}=606.32 \mathrm{~N}$

$\mathrm{RC}$ due to bearing support at $\mathrm{C}=770.19 \mathrm{~N}$

$\mathrm{P} 2$ due to the weight of the pulley at $\mathrm{D}=9.81 \mathrm{~N}$

Total uniformly distributed load $=1366.7 \mathrm{~N}$
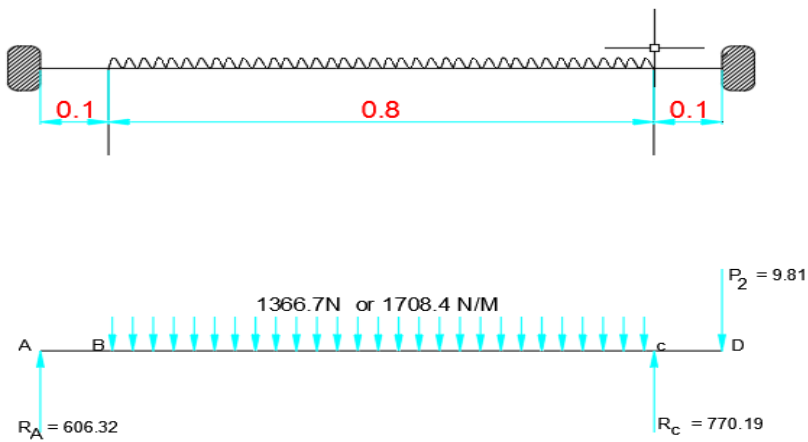

The yield strength $(\sigma y)$ of the shaft of $40 \mathrm{~mm}$ diameter can be obtained from the AISI series
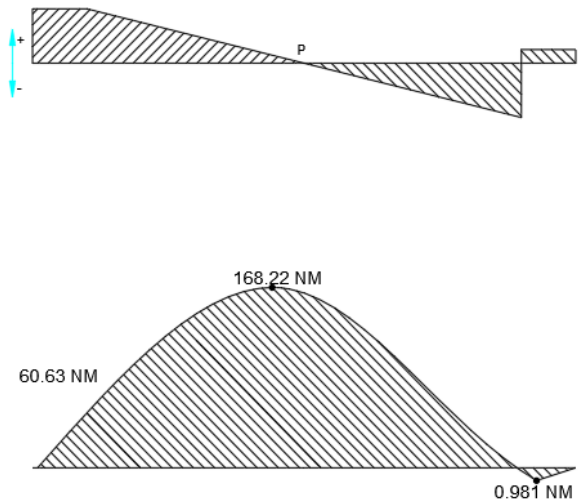

Fig. 10: Vertical load, Shear Force and bending moment diagram

The maximum bending moment is determined for this design. The shaft is neglected.

Recalling Tresca Theory of Failure

$T_{d}=\frac{16}{d^{3}}\left(M^{2}+T^{2}\right)^{\frac{1}{2}}$

And introducing the fatigue factors 
$T_{d}=\frac{16}{d^{3}}\left(K b M^{2}+K t T^{2}\right)^{\frac{1}{2}}$

Where

$\mathrm{D}=$ diameter of the shaft

$\mathrm{M}=$ Maximum bending moment

$\mathrm{T}=$ Torque transmitted by the belt drive

$T_{d}=$ Design shear stress

The power delivered to the shaft could be obtained as expressed in equation (17)

Power $=\left(T_{1}-T_{2}\right) V x$ no of belt

$\mathrm{V}=\omega \mathrm{r}$

Where $\omega=$ angular velocity, $\mathrm{r}=$ radius of the machine

Horse power rating of the Electric motor

3 h.p $=(3 \times 746)$ watts $=2.238 \mathrm{Kw}$

Speed of the driven pulley is expected to $400 \mathrm{rpm} . \quad \mathrm{Ns}=400 \mathrm{rpm}$

Power $=$ Torque $\mathrm{x}$ Angular velocity in $\mathrm{rad} / \mathrm{s}$

$P=T \omega$

$\mathrm{T}=53.42 \mathrm{~N} \cdot \mathrm{m}$

The maximum shear theory of static failure state

$\mathrm{T}_{\mathrm{m}}=\frac{\sigma y}{2}$

But $\sigma y=207 \times 10^{6} \mathrm{~N} / \mathrm{m}^{2}$

$\mathrm{T}_{\mathrm{m}}=\frac{207 \times 10}{2}=103.5 \times 10^{6} \mathrm{~N} / \mathrm{m}^{2}$

Also, $n s \quad \times n_{l}=1.5 \times 4=6$

$T_{d}=\frac{T_{m}}{6}=\frac{16}{d^{3}}\left(K b M^{2}+K_{E} t T^{2}\right)^{\frac{1}{2}}$

The value of the diameter $\mathrm{d}$ as obtained is $39.8 \mathrm{~mm}$. A shaft of diameter $40 \mathrm{~mm}$ is thus selected

For the most efficient shelling, the pegs are employed and pegs assists the progression of the cobs along the cylinder and ensure the removal of all maize from the smallest cobs. They are spaced at regular intervals. The pegs are arranged to form spiral shape or inform of screw conveyor to take the cobs into right hand side.

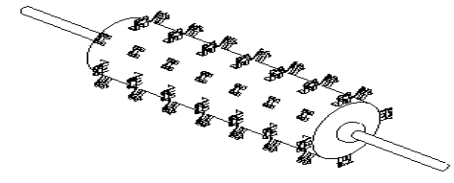

Fig. 11: Shelling drum

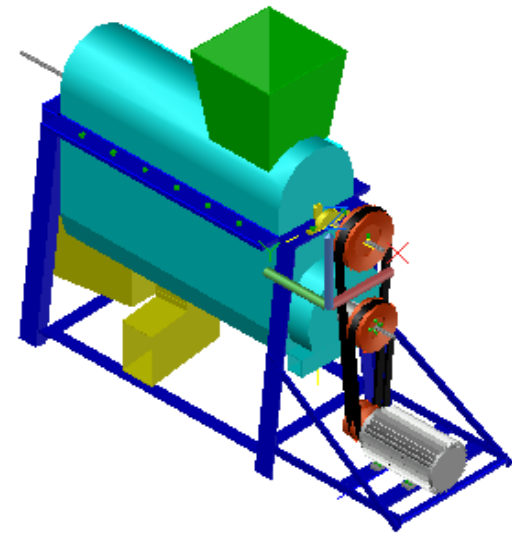

Fig. 12: Motorized Maize Sheller 


\section{PERFORMANCE TEST}

The shelling machine was subjected to test and it was discovered to thresh maize very effectively having negligible Losses and breakages. The estimated capacity of the machine is about $0.6-0.8$ ton per hour. The efficiency of the machine was calculated from the equation below to be equal to $99.2 \%$ :

Efficiency $=\left\{\left(W_{1}-W_{2}\right) \mid W_{1}\right\} \times 100$

Where $W_{1}$ is the weight of unthreshed cobs and $W_{2}=$ weight of cobs not well threshed

\section{CONCLUSION}

From the result above, the machine was successfully designed with the throughput capacity $(600-800 \mathrm{~kg} / \mathrm{hr}$.) which is far better than the actual human throughput capacity determined to be $21 \mathrm{~kg} / \mathrm{hr}$. It could be concluded that this project is of the best interest of the agricultural productivity and well reducing the force exerted on the shelling of maize by relieving the stress on the labour.

\section{REFERENCES}

[1]. Naveenkumar D.B. (2011). Modification and Evaluation of Power Operated Maize Sheller. PAK 9304.

[2]. Okaka J.C. (1997). Cereals and Legumes: Storage and Processing Technology. Data and Micro System Publisher, Enugu, Nigeria pp, 11-124.

[3]. Abdulkadir B.H; Matthew S.A.; Olufemi A.; and Ikechukwu C.U. (2009). The design and construction of Maize Threshing Machine. AU J.T. 12(3): 199-206.

[4]. Adewole, C.A.; Babajide, T.M.; Oke, A.M.; Babajide, N.A.; Aremu, D.O.; and Ogunlade, C.A. (2015). Critical Evaluation of Locally Fabricated Maize Shelling Machine. International Journal of Engineering Science and Innovation Technology (IJESIT) vol 4, Issue 2.

[5]. Anirudha, G.D.; Dr. C.C. Handa. (2015). Design Consideration of Corn Sheller Machine. International Journal for Innovative Research in Science and Technology, Volume 2, Issue 02.

[6]. Tanko Bako, Boman James Bature (2017). Design Fabrication and Performance Evaluation of a Hand Operated Maize Sheller.http://www.sciencepub.net/ researcher 9(3):39-47.

[7]. Aremu, D.O.; Adewumi, I.O.; Ijadumola, J.A. (2015). Design, Fabrication and performance Evaluation of a Motorized Maize Shelling Machine. Vol.5, No.5

[8] Dr. B.S.K.K.V.; Dapoli; Ratnagiri. (2008). Design, Development and Evaluation of a Power Operated Maize Sheller (spiked Disk Type) J. Agric. Sci. Vol.4 No.1, pp: 215-219.

[9] Joshi, H.C. (1998). Design and selection of thresher parameters and components. Journal of Agricultural Mechanization in Asia, Africa and Latin America; Vol. 12(2), 61-70.

[10] Praveen K.M.; Sakhale C.N.; Shelare S.D. (2015). A Literature Review on Design and Development of Maize Thresher. IJPRET, Volume 3 (9): 9-14.

[11] Prof.Pradip; Mr. Abhijeet Y.K.; Mr. Arjun B.M.; Mr. Nadeem H.N.; and Mr. Rahul A.D. (2017). A Research on Peeling-Shelling Compact Combo Machine. IJRET, Volume 4, Issue 04.

[12] Desai S.R; Jankar V.G.; Mali P.S.; Nikade A.M; Patilvikas S. (2017). Design and Development of Corn Chaff Peeling Machine. IJAERD, Volume 4, Issue 3.

[13] Mandar M.S.; (2018). Design and Fabrication of a Motorized Corn Shelling Machine. Researchgate, Conference Paper. 
[14] Hamid Fadhil Al-jalil (1978). 'Design and Performance of Low Damage Corn Shelling Machines'. Lowa State University Capstones, Theses and Dissertations. Pp159-163.

[15] Kaul, R.N.; and Egbo, C.O. (1985). Introduction to agricultural mechanization. Macmillan, London, England, UK. pp. 128-41.

[16] Spotts, M.F. (1985). Design of machine elements. 6th ed. Prentice Hall, Englewood Cliffs, NJ, USA.

[17] PSG Tech. (1989). Design data. Faculty of Mechanical Engineering, Poolamedu Sathankulam Govindsamy Naidu College of Technology (PSG Tech), DPV Printers, Coimbatore, India.

[18] Girish Karikatti,Jangali Satish J, Anjali Kathani, RoopaLokeshwar, Sameer Sattur (2015). Crank Operated Maize Sheller. International Journal for Scientific Research \& Development| Vol. 3, Issue 04.

[19] Anirudha G. DarudkarDr. C. C. Handa (2015). Literature Review of Corn Sheller Machine International Journal for Innovative Research in Science \& Technology| Volume 2 | Issue 01.

[20] Adetunji O. R., Balogun B. A., and Fasasi A. T. (2018) Development of a Motorized Maize Shelling Machine. UmudikeJournal of Engineering and Technology (UJET), Vol. 4 no. 2.

[21] Pavasiya Uttam N, Patel Hardik, Patel Krupesh, Sumant Mandar Mukundrav and Sutariya Hiren R. (2018). Design \& Fabrication of a Motorized Maize Shelling Machine. Journal of Material Science and Mechanical Engineering (JMSME) Volume 5, Issue1; pp. 5-12.

[22] R.S. Bello and C. Fabian (2018). Development and Performance Evaluation of a Spring-Loaded Hand Operated Maize Sheller with Variable Mechanisms. International Journal of Engineering and Technologies Vol. 15, pp 44-52. 